\title{
Comparison of Seismic Response of RCC Framed Structure With FPB \& HDRB Isolators
}

\author{
Samiksha Pachbiye \\ ${ }^{1}$ Department of Structural Engineering, Govt Engineering College, Darampura, Jagdalpur, Chhattisgarh 494001 \\ Corresponding Author; Email: samikshapachbiye@gmail.com
}

\begin{abstract}
Base isolation technique is introduced to improve the performance of the building. The base isolation technique is used to decouple the base from its superstructure during the ground motion caused by earthquakes. The installation of isolator in a building at a base level significantly increases the time period of the structure which means it reduces the possibility of resonance of the structure giving rise to better seismic performance of the building. The main aim of this paper is the use of Friction Pendulum Bearing (FPB) and High- Density Rubber Bearing (HDRB) as an isolation device and then to compare various parameters between fixed base condition and base-isolated condition. The modeling procedure for both building has been done using ETABS 2017 software for a regular $(G+5)$ storied OMRF building. Linear analysis using Time History Analysis (THA) for the records of Elcentro earthquake (1940) and Response spectrum analysis (RSA) has been carried out.
\end{abstract}

Key Words: Base Isolation, FPB, HDRB, Time History analysis (THA) and Response spectrum analysis (RSA)

\section{Introduction}

Base isolation, also known as seismic base isolation is one of the most popular means of protecting a structure against earthquake forces. It's a set of structural components that ought to well decouple a superstructure from its substructure resting on a shaking ground, thus protecting a structure's integrity. Generally, passive control is more studied and applied to the existing buildings than the others. Base isolation is a passive vibration control system that does not require any external power source for its operation and utilizes the motion of the structure to develop the control forces.

The Base isolation system is a frequently adopted earthquake resistance system. It reduces the impact of ground motion and therefore results in nullify the effect of earthquake on the structure. Base isolation has become in style within the last few decades in its implementation in building and bridge. Base isolation has become a standard concept for structure style and bridge in speculative areas.

\section{Base Isolated System}

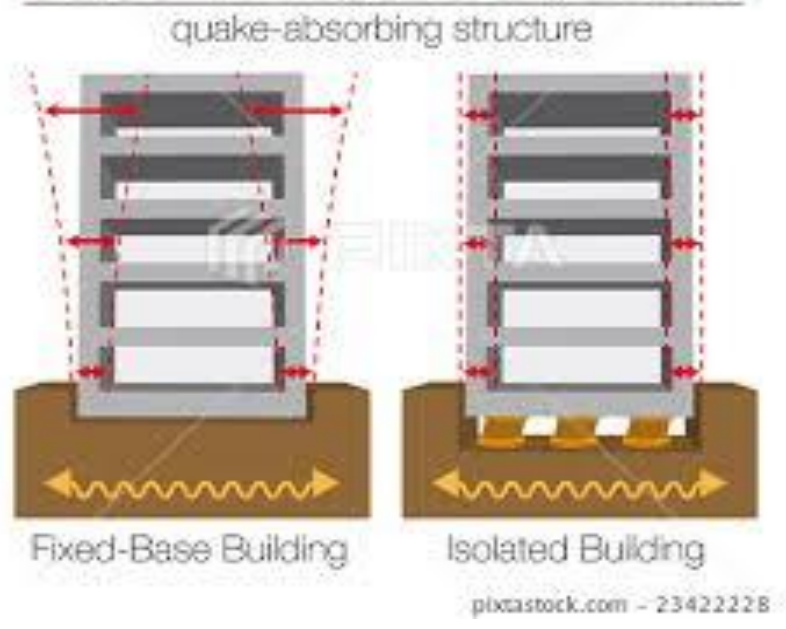


The isolation system decouples the structure from the horizontal elements of the ground motion by interposing structural components with low stiffness between the History analysis and Response Spectrum analysis foundation and superstructure. This concept has received increasing educational and skilled attention is being applied to a good vary of civil engineering structures.

\section{Types of Bearings}

There are two families of isolators particularly elastomeric bearing and sliding bearing. The first category of elastomeric bearings, within which we discover the High Damping Rubber Bearing system (HDRB), the Lead Rubber Bearing System (LRBs) and other systems. The second category includes the family of sliding bearings, within which we tend to found the Friction Pendulum System (FPS) and sliding bearing system. Many buildings were made or retrofitted using one type of isolation systems. The main objective of this project is to compare the fixed base and base-isolated structure by dynamic analysis. The results were compared for Base shear, displacements and storey drift.

The objective of the project is as explained below: -

- Model and analyze the response of an RCC structure with a fixed based.

- To compare the response of the building such as time period, base shear storey drift and storey displacement of $\mathrm{RC}$ building with and without base-isolation in Etabs by considering time history analysis for Elcentro earthquake and response spectrum analysis.

- Analyze the seismic effect on the baseisolated structure. Evaluate the analysis technique and design criteria used in baseisolated structure

- To study the behavior of earthquake resisting base-isolated buildings.

\section{Modeling and Analysis}

The modeling of fixed base and base isolated building is done by ETABS 2017 software. G+5 stories RCC building is considered with fixed base and base isolated with two different isolators they are friction pendulum bearing and High-density rubber bearing. Time history analysis and response spectrum analysis is done by using Elcentro data.

Table 1 Building Details

\begin{tabular}{|l|c|}
\hline Type of building & $\begin{array}{c}\text { Residential } \\
\text { apartment }\end{array}$ \\
\hline Height of building & $18 \mathrm{~m}$ \\
\hline Floor height- & $3 \mathrm{~m}$ \\
\hline Grade of concrete & $\mathrm{M} 25$ \\
\hline Steel grade & $\mathrm{Fe} 415$ \\
\hline Slab thickness & $150 \mathrm{~mm}$ \\
\hline Size of beam & $300 \mathrm{~mm} 5500 \mathrm{~mm}$ \\
\hline Size of column & $300 \mathrm{~mm} \times 500 \mathrm{~mm}$ \\
\hline Live load on floor & $4 \mathrm{kN} / \mathrm{m}^{2}$ \\
\hline Floor Finish & $1 \mathrm{kN} / \mathrm{m}^{2}$ \\
\hline
\end{tabular}

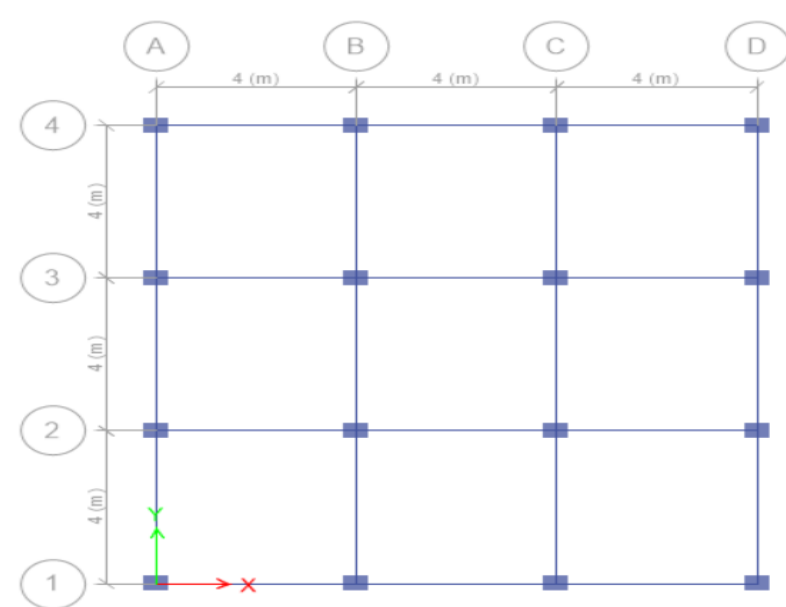

Fig 1 Plan of proposed building 
Table 2 Properties of isolators for $\mathrm{G}+5$

\begin{tabular}{|l|l|l|}
\hline Type & FPS & HDRB \\
\hline $\begin{array}{l}\text { Vertical Stiffness } \\
\text { (U1) }\end{array}$ & $\begin{array}{l}19256250 \mathrm{kN} / \\
\mathrm{m}\end{array}$ & $\begin{array}{l}12081.8 \mathrm{k} \\
\mathrm{N} / \mathrm{m}\end{array}$ \\
\hline $\begin{array}{l}\text { Linear Stiffness } \\
\text { (U2\&U3) }\end{array}$ & $6355.2 \mathrm{kN} / \mathrm{m}$ & $\begin{array}{l}227.84 \\
\mathrm{kN} / \mathrm{m}\end{array}$ \\
\hline $\begin{array}{l}\text { Non-linear } \\
\text { Stiffness } \\
\text { (U2\&U3) }\end{array}$ & $\begin{array}{l}19256.25 \mathrm{kN} / \\
\mathrm{m} /\end{array}$ & $\begin{array}{l}8699.06 \\
\mathrm{kN} / \mathrm{m}\end{array}$ \\
\hline Damping co- & 0.05 & 0.05 \\
\hline $\begin{array}{l}\text { Friction } \\
\text { efficient, Slow co- }\end{array}$ & 0.03 & \\
\hline $\begin{array}{l}\text { Friction } \\
\text { efficient, Fast }\end{array}$ & 0.05 & \\
\hline $\begin{array}{l}\text { Radius of Sliding } \\
\text { Surface }\end{array}$ & $1.5 \mathrm{~m}$ & \\
\hline
\end{tabular}

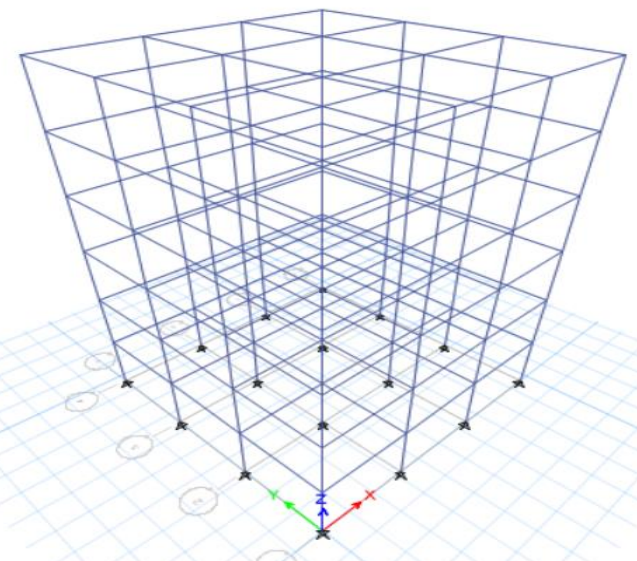

Fig 2 3D view of the proposed building

\section{Result and Discussion}

The results show that the time period and storey displacement are increased in both the isolated building as compared to fixed base and base shear and storey drift is reduced by using the isolator. This suggested that base-isolation is an effective earthquake resistant technique for medium-rise structures.

\section{Storey Displacement}

The graph shows the storey displacement for the structure, it is observed that the total maximum displacement is higher in the case of an isolated building.

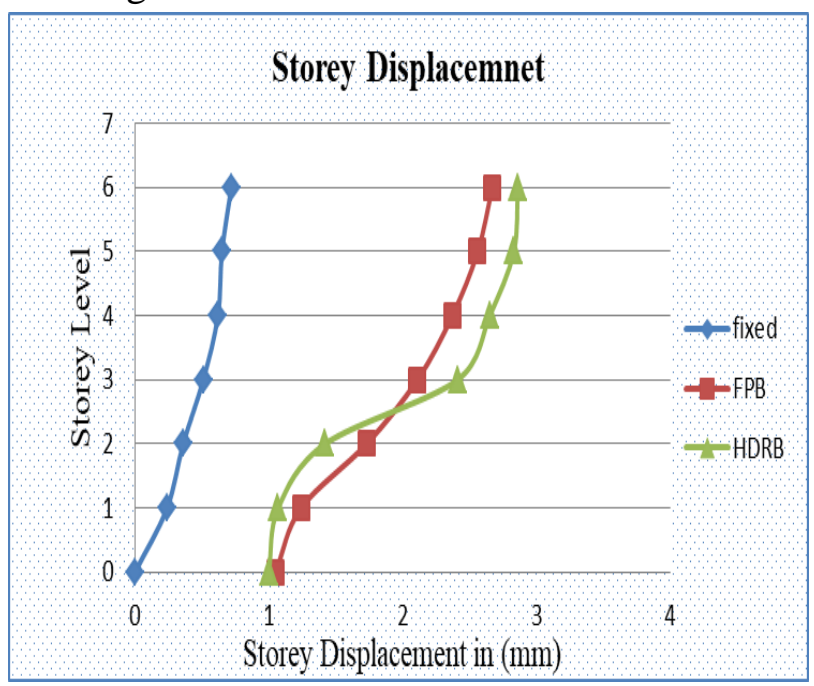

Fig 3 Graph of Storey Displacement

\section{Storey Drift}

It is observed that the story drift for the fixed base building is much more than that of baseisolated building.

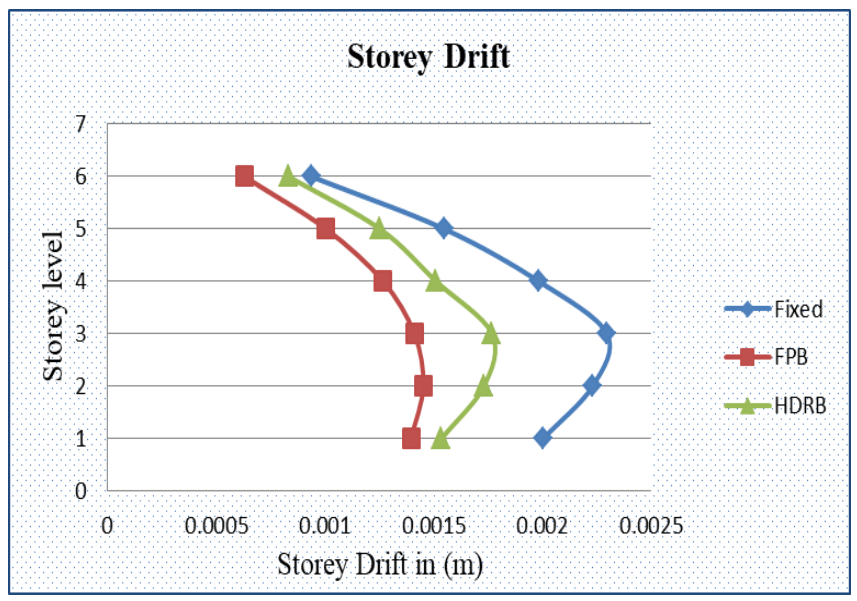

Fig 4 Graph of Storey Drift

\section{Storey Shear}

The graph shows the storey shear which is reduced in base-isolated buildings compared to fix based. 


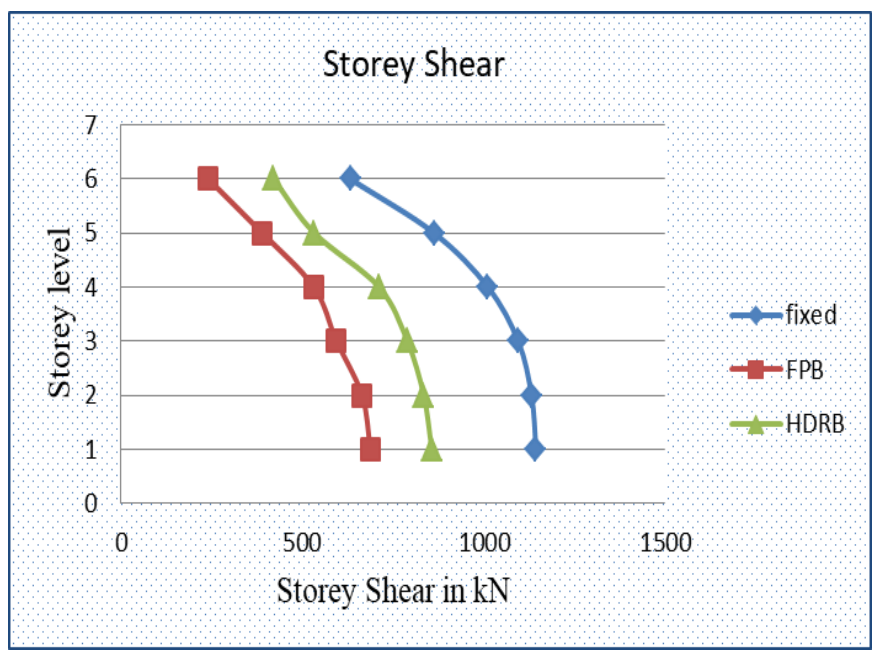

Fig 5 Graph of Storey Shear

\section{Storey Overturning Moment}

The graph shows the overturning moment of the structure.

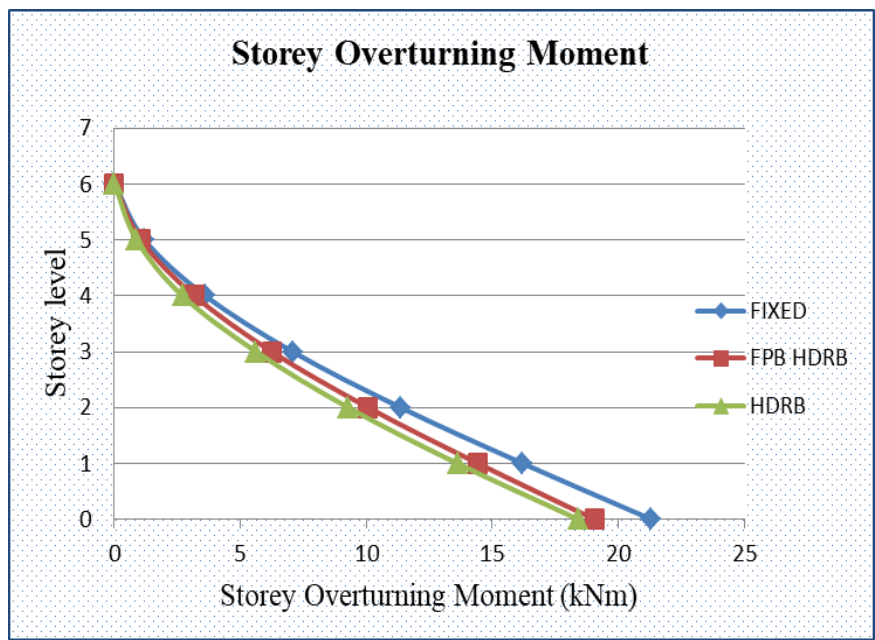

Fig 6 Graph of Overturning Moment

\section{Base Shear}

The graph shows that the base shear is reduced in base-isolated structure as compared to a fixed base.

\section{Conclusion}

i. Base isolation method has proved as a promising solution of earthquakeresistant design

ii. The result shows that the response of the structure can be reduced by using Friction Pendulum bearing and HighDensity Rubber Bearing.

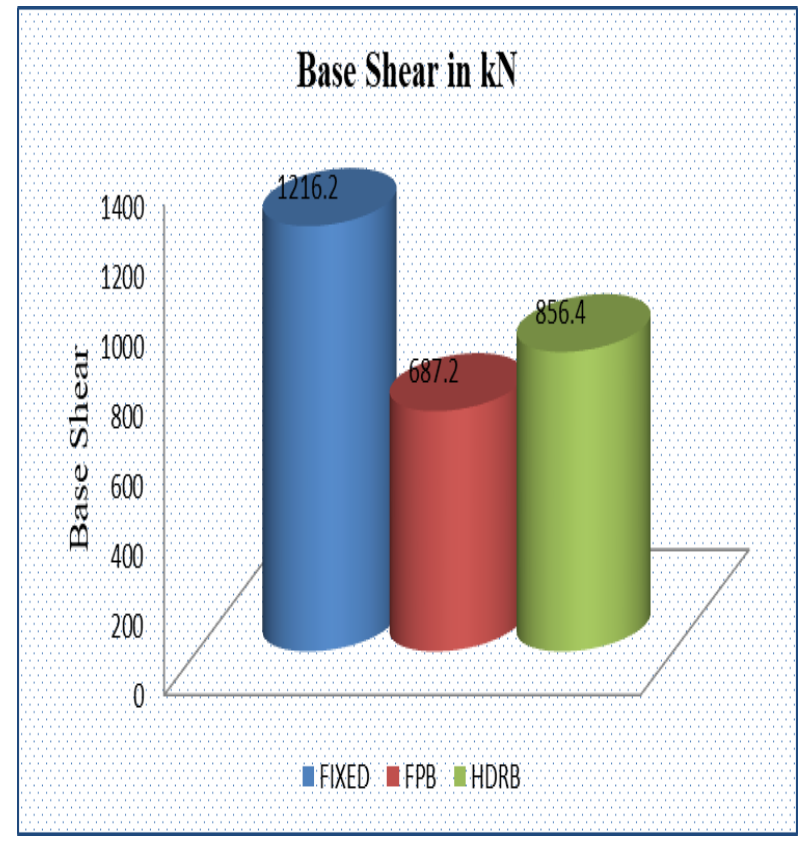

Fig 7 Graph of Base Shear

iii. Time period of both the base isolated structure increases as compared to fixed base.

iv. The result shows that the storey displacement increases and storey drift reduced in both the isolated building over the conventional structure.

v. The base shear is reduced in both the building by using FPS and HDRB.

\section{Conflict of Interest}

The authors declare no conflict of interest.

\section{References}

[1] Akhare, A. R., \& Wankhade, T. R. (2014). Seismic performance of RC structure using different base isolator.

[2] Reddy, M. R., Srujana, N., \& Lingeshwaran, N. (2017). Effect of base isolation in multistoried reinforced concrete building. International Journal of Civil Engineering and Technology, $8(3), 878-887$. 
Pachbiye 2020 Comparison of Seismic Response of RCC Framed Structure with FPB \& HDRB Isolators

[3] Patil, S. J., \& Reddy, G. R. (2012). State

of art review-base isolation systems for structures. International journal of emerging technology and advanced engineering, 2(7), 438-453.

[4] Wen, P. A. N., \& Baifeng, S. U. N. (2008, October). Two Step Design Method For Base Isolation Structures. In The 14th World Conference on Earthquake Engineering October (pp. 12-17).

[5] IS 456-2008, IS codes for RCC and Earthquake-resistant Design respectively.

[6] Abd Hacheem, Z., \& AL-Shimmari, A. L. I. K. (2010). Finite element analysis of a friction pendulum bearing base isolation system for earthquake loads. Journal of Engineering, 16(3).

[7] Zayas, V., and Stanley Low, S. M. (1987). "The FPS earthquake resisting system experimental report", Report No. UCB/EERC 87/01, University of California, Berkeley Earthquake Engineering Research Center.

[8] Fenz, D. M., \& Constantinou, M. C. (2006). Behaviour of the double concave friction pendulum bearing. Earthquake engineering \& structural dynamics, 35(11), 1403-1424.

[9] Fenz, D. M., \& Constantinou, M. C. (2008). Modeling triple friction pendulum bearings for response-history analysis. Earthquake Spectra, 24(4), 1011-1028.

[10] Education', Proceedings of the 2008 American Society for Engineering Education Pacific Southwest Annual Conference. 